\title{
INTEGRAÇÃO DAS TÉCNICAS DE REFRAÇÃO E REFLEXÃO SÍSMICA RASA APLICADA AO ESTUDO DE BARRAGENS-UHE PIRAJU II
}

\author{
Rafael Ludwig Herzig \\ Orientador: Dra. Liliana Alcazar Diogo (IAG/USP) \\ 167 p - Dissertação (Mestrado) - Defesa 11.06.2003
}

RESUMO. No presente trabalho foi proposta a integração de dados de refração e reflexão sísmica rasa para se obter informações estruturais de subsuperfície que subsidiarão um projeto de construção de barragem. 0 principal objetivo da utilização do método de reflexão foi verificar a existência de arenitos intertrapianos e imagear o topo e a base desses arenitos. A técnica de refração foi utilizada para estudar o substrato próximo da superfície. Tanto os dados de reflexão como os de refração sísmica revelaram uma estrutura próxima da superfície muito complexa. Foi detectada uma camada fina de espessura variável abaixo da cobertura de baixa velocidade e a cima, ao topo do basalto, o que consistiu em um problema de camada semiescondida para o método de refração, sendo necessária uma maior densidade de dados para a sua caracterização. Os dados de reflexão sísmica apresentaram-se fortemente afetados por distúrbios de estática e superposição de reverberações. As etapas de processamento efetuadas sobre os registros de reflexão proporcionaram uma sensível melhora na razão sinal/ruído e na resolução dos dados. Apesar de todos os recursos empregados, ainda assim, as reflexões interpretadas como sendo o topo do arenito sofrem a influência da superposição de outros eventos, e por isso a imagem não é uniforme ao longo de toda a seção. Como não foi possível a determinação precisa do modelo intervalar de velocidades acima do topo do basalto, têm-se uma estimativa da ordem de valores associados a profundidade do topo do arenito. Acredita-se que 0 trabalho desenvolvido apresenta resultados promissores encorajando a continuidade da pesquisa com o objetivo de avaliar a aplicação do método sísmico em terrenos complexos, com interesse para a geologia de engenharia.

ABSTRACT. We proposed to integrate seismic reflection and refraction data to get subsurface information in order to aid a dam construction project. The main objective of the reflection survey was to image a contact of Basalt/Sandstone and the bottom of the sandstone layer. The refraction technique was used to study the upper near surface structure. Both reflection and refraction seismic data showed that the near surface structures are very complex. It was detected a thin bed with variable thickness between the low velocity layer and the basalt, which was a semi-hidden layer to the refraction method, requiring more refraction data density to characterize them. Seismic reflection data was severely affected by statics and reverberations. Digital data processing was able to increase the resolution and signal-to-nose ratio. However, the interpreted reflections on the top of the sandstone is yet affected by the superposition of other events and the reflector image is not uniform on the whole stacked section. It was not possible to obtain accurate interval velocity model above the basalt top, but it was possible to reach an estimate of the values for the sandstone top depth. The work has shown promising results so far, and the continuity of the seismic application in this project is encouraging, with the objective of assessing the applicability of the seismic methods in complex terrain of the engineering geology applications. 